\title{
Sex cord tumor with annular tubules in patients with Turner syndrome: Mosaicism 45X/46XY
}

\section{Tumor de cordones sexuales con túbulos anulares en paciente con síndrome de Turner: mosaicismo 45X/46XY}

\author{
María Alejandra Sánchez ${ }^{1}$ Angie Lizeth Garzón ${ }^{2}$ Jaime Pérez ${ }^{3}$ Adam B. Hittelman ${ }^{4}$ \\ Camila Céspedes $^{5}$ Catalina Forero $^{5}$ Nicolás Fernández ${ }^{6}$
}

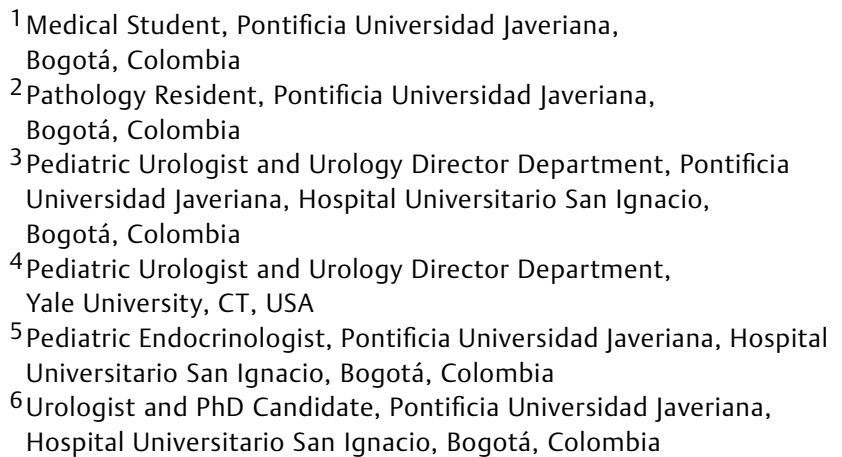

Address for correspondence María Alejandra Sánchez, Medical Student, Pontificia Universidad Javeriana, Bogotá, Colombia (e-mail: malesan93@hotmail.com).

\author{
Abstract \\ Keywords \\ - turner syndrome \\ - gonadal dysgenesis \\ - sex cord stromal \\ tumor \\ - mosaicism \\ - Y chromosome \\ - gonadoblastoma
}

Introduction It has been described among the literature the close relationship that exists between dysgenetic gonads with positive $Y$ chromosome and the risk of developing gonadoblastoma. However, it is still uncertain the relationship with stromal tumors and there is not much information about this topic. In this paper is presented the case of a patient with Turner syndrome mosaicism $45 \mathrm{X}(8) / 46, \mathrm{XY}(92)$ and sex cord tumor with annular tubule pattern.

Materials and methods A search was conducted in Embase, Ovid, Ebsco and PubMed databases with the terms "(Turner syndrome) and sex cord stromal tumor". However, only in PubMed we were able to find an article that meets the search criteria and it is considered the first case report in the literature that refers to the relationship between Turner syndrome and sex cord stromal tumor.

Conclusions There is little evidence that exists for cases like this, so the management of these patients is still uncertain and controversial, especially by the different perspectives in-between specialties. Specifically, with this patient it is still uncertain the relationship between the risk and the benefit of the management with growth hormone after the finding of neoplasm. received

November 30, 2016

accepted

March 13, 2017

published online

January 10, 2018
DOI https://doi.org/

10.1016/j.uroco.2017.03.005.

ISSN 0120-789X.

eISSN 2027-0119.
Copyright (c) 2018, Sociedad Colombiana License terms de Urología. Publicado por Thieme Revinter Publicações Ltda., Rio de Janeiro, Brazil. Todos los derechos reservados. 


\section{Resumen}

\section{Palabras clave \\ - síndrome de turner \\ - disgenesia gonadal \\ - tumor estromal de cordones sexuales \\ - mosaicismo \\ - cromosoma $Y$ \\ - gonadoblastoma}

Introducción En la literatura se ha descrito la estrecha relación que existe entre gónadas disgenéticas con presencia del cromosoma $\mathrm{Y}$ y el riesgo de desarrollar gonadoblastoma. Sin embargo, se sabe poco y es incierta la relación que existe con tumores estromales de cordones sexuales. En este trabajo se presenta el caso de una paciente de 14 años años con síndrome de Turner, 45X (8)/46XY(92) con tumor de cordones sexuales con patrón anular.

Materiales y métodos Se realizó una búsqueda en las bases de datos de Embase, Ovid, Ebsco y PubMed con los términos "(Turner Syndrome) AND Sex cord stromal tumor». Sin embargo, solo en PubMed se encontró un artículo que cumpliera con los criterios de búsqueda, y este se considera el primer reporte de caso en la literatura que hace referencia a la relación entre el síndrome de Turner y tumor estromal de cordones sexuales.

Conclusiones Es poca la evidencia que existe para casos como este, por lo cual el manejo de estos pacientes es aún incierto y controvertido, en especial por las diferentes perspectivas de las especialidades tratantes. Específicamente con esta paciente tenemos la dificultad de definir el riesgo-beneficio del manejo con hormona de crecimiento como parte de su tratamiento luego de tener el resultado neoplásico.

\section{Introduction}

The incidence of Turner syndrome is approximately 2500 women born alive, making it one of the most frequent chromosomal abnormalities in the world. ${ }^{1}$ of the total cases, about 6-9\% have a mosaic karyotype, with Y chromosome or abnormal fragments. ${ }^{2}$ The presence of these dysgenetic gonads increases the risk of gonadal tumors, especially of gonadoblastoma. ${ }^{2-4}$ Among other less common tumors there are embryonal carcinoma, choriocarcinoma or endodermal sinus tumor. ${ }^{5}$

Stromal tumors are less frequent in these cases. There is only one case that has been reported in the literature with a sex cord tumor with annular tubules in a patient with mosaicism $45 \mathrm{X} / 46 \mathrm{XX} .^{5}$ We present the case of a 14 year old girl with Turner syndrome, $45 \mathrm{X}(8) / 46, \mathrm{XY}(92)$ and sex cord tumor with annular pattern.

\section{Case report}

A 14-year-old initially seen because of short stature. No significant prenatal history or relevant childhood medical records. Paraclinical studies reported ovarian failure, for which genetic evaluation was recommended.

G-banding karyotype reported 45X(8)/46XY(92). Comparative genomic hybridization $(\mathrm{CGH})$ study confirmed the presence of chromosome $Y$. The analysis revealed number loss of copies for all probes of chromosome X 155.2.71 MB and detected gain of copies for all probes of $Y$ chromosome. Consistent finding with the previous cytogenetic study that showed sex chromosome mosaicism. CGH reveals $9 \%$ of $46 X Y$ mosaic and $93 \%$ of $45 \mathrm{X}$. Additionally a gain of copies was detected on chromosome 12 in the bands 12q21.31, gain in yp11.32q11.223 and loss in xp22.33q28.

She was assessed by a transdisciplinary group who suggested bilateral gonadectomy by laparoscopy, given the high risk of gonadoblastoma. Intra-abdominal gonads were identified with some white indurated lesions suggestive of malignancy. A wide resection with large margins was performed (- Fig. 1A and B). Pathology result identified a left gonad with uterine tube segment and the presence sex cord tumor with annular tubular morphology and abundant calcifications confirmed by immunohistochemistry. It shows positivity in tumor cells for calretinin, CD99, CK AE1-AE3, Melan A, inhibin and negativity for PLAP was identified.

As for the microscopic findings, it is known that there are several similarities between the gonadoblastoma and sex cord stromal tumor, so it required an extensive histological study for its characterization and classification. When performing histological sections, the linchpin for the classification of the tumor was found. There can be observed many simple ringshaped tubules and peripheral cores around a central hyalinized body, which is considered an annular pattern (-Fig. 2).

In addition, many foci of calcification were found in the cuts (-Fig. 3), which are characteristic and compatible with the gonadoblastoma, as well as the discovery of germ cells in the extracted tissue with a testicular pattern and clusters of Sertoli cells. Even an ovarian follicle was found in the sample, confirming the presence of ovarian gonadal dysgenesis (-Fig. 4).

Therefore, the realization of special stains with immunohistochemical markers was considered necessary, which served to exclude the diagnosis of gonadoblastoma. At first, the negativity of placental alkaline phosphatase (-Fig. 5) and confirmed by the positivity in calretinin, Melan A, CK AE1/AE3 and CD99 markers corresponding to sex cord tumor (-Fig. 6).

\section{Discussion}

In the literature, it has been extensively described the close relationship that exists between dysgenetic gonads with presence of the Y chromosome and the risk of developing 

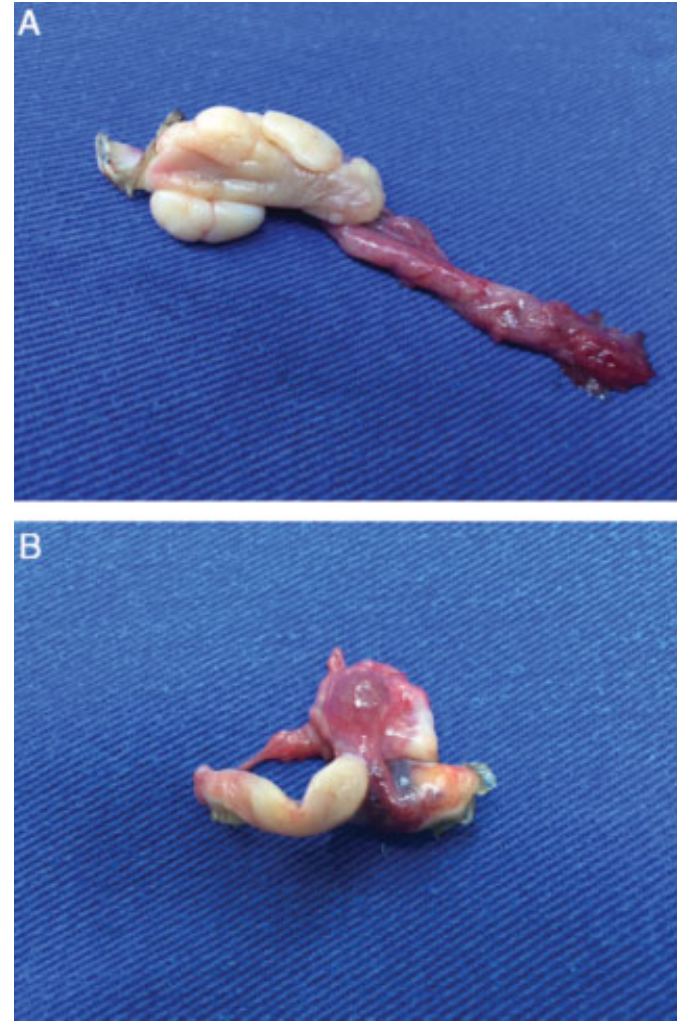

Fig. 1 Macroscopic findings after surgical resection. (A) Right gonad weight $3 \mathrm{~g}$ and measured $2.8 \times 2.5 \times 2 \mathrm{~cm}$, additionally it has a tubular segment with $1.5 \times 0.8 \mathrm{~cm}$. When cut, homogeneous parenchyma was found. (B) Left gonad, weighed $4.3 \mathrm{~g}$ and measured $3.3 \times 3 \times 2.8 \mathrm{~cm}$ plus the tubular segment $3.6 \times 0.8 \mathrm{~cm}$. When cut, there was whitish homogeneous parenchyma.

malignancies, especially gonadoblastoma. However, there is little evidence and it is uncertain the relationship with sex cord stromal tumors, which implies a challenge in the management of these patients.

It is known that there is a high risk of gonadal tumor in patients with Turner syndrome for which the evidence recommend surgical removal of both gonads and it should be consider making histological sections and special immunohistochemical staining's as extension study for tumor characterization.

In this case, the finding of sex cord tumor has implications for the management and prognosis of the patient, since despite it is considered a benign tumor, there have also been reported cases of malignant transformation in $20 \%$ of the cases. ${ }^{6}$ This not only reaffirms the need for surgery but at the same time it limits medical management, for example for the use of growth hormone in patients with short stature, characteristic phenotype of Turner syndrome. It has been described that growth hormone and its axis influence various stages of cancer development, this related to angiogenesis and cell proliferation since this is a powerful mitotic agent. ${ }^{7}$

\section{Ethical disclosures}

\section{Protection of human and animal subjects}

The authors declare that no experiments were performed on humans or animals for this study.
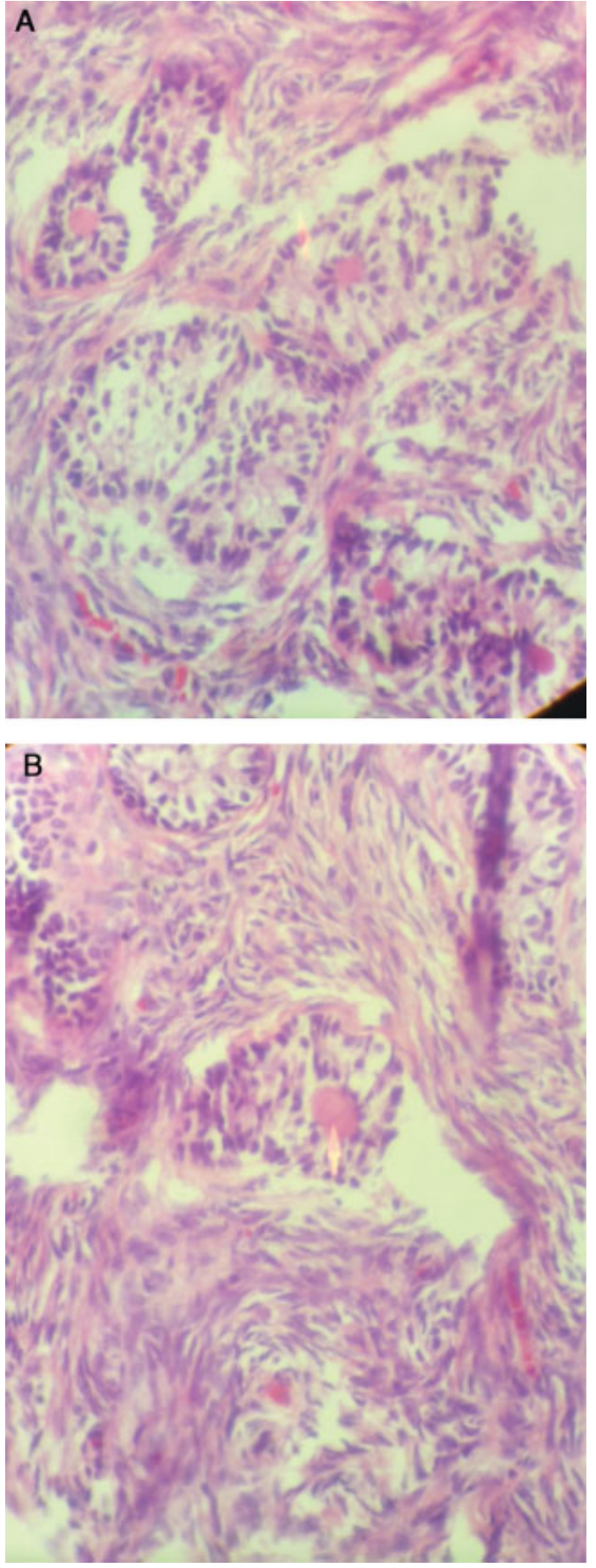

Fig. 2 Microscopic findings. (A) Anular pattern. (B) The arrow signals the central hyalinized body of the ring shaped tubule.

\section{Confidentiality of data}

The authors declare that they have followed the protocols of their work center on the publication of patient data.

\section{Right to privacy and informed consent}

The authors have obtained the written informed consent of the patients or subjects mentioned in the article. The corresponding author is in possession of this document. 


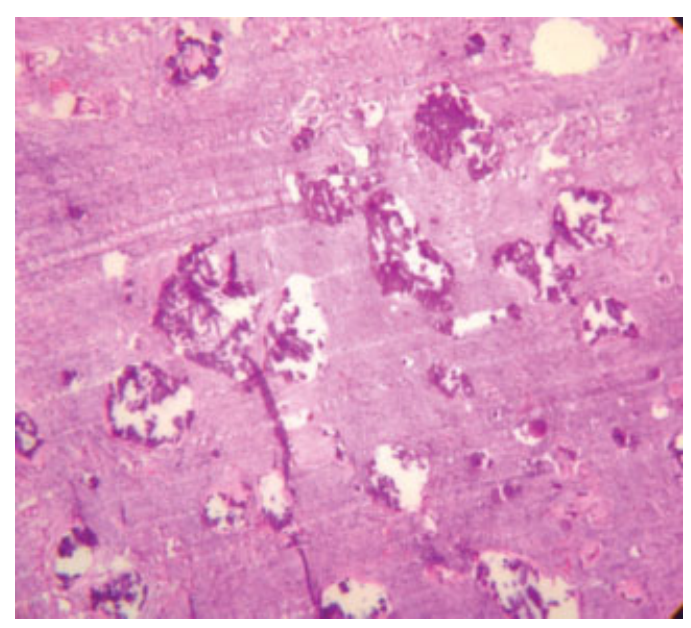

Fig. 3 Calcification foci stain with $\mathrm{H}-\mathrm{E}$.

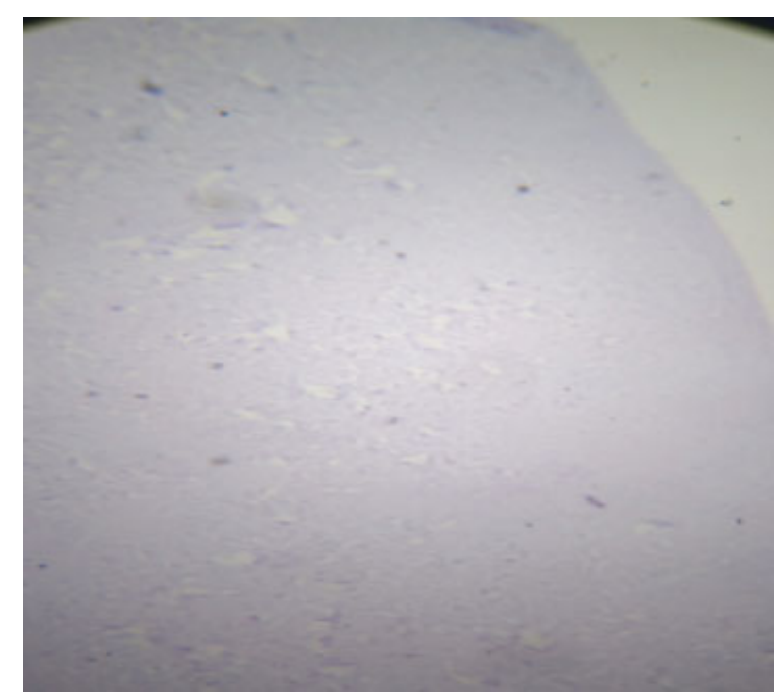

Fig. 5 Immunohistochemical markers: placental alkaline.
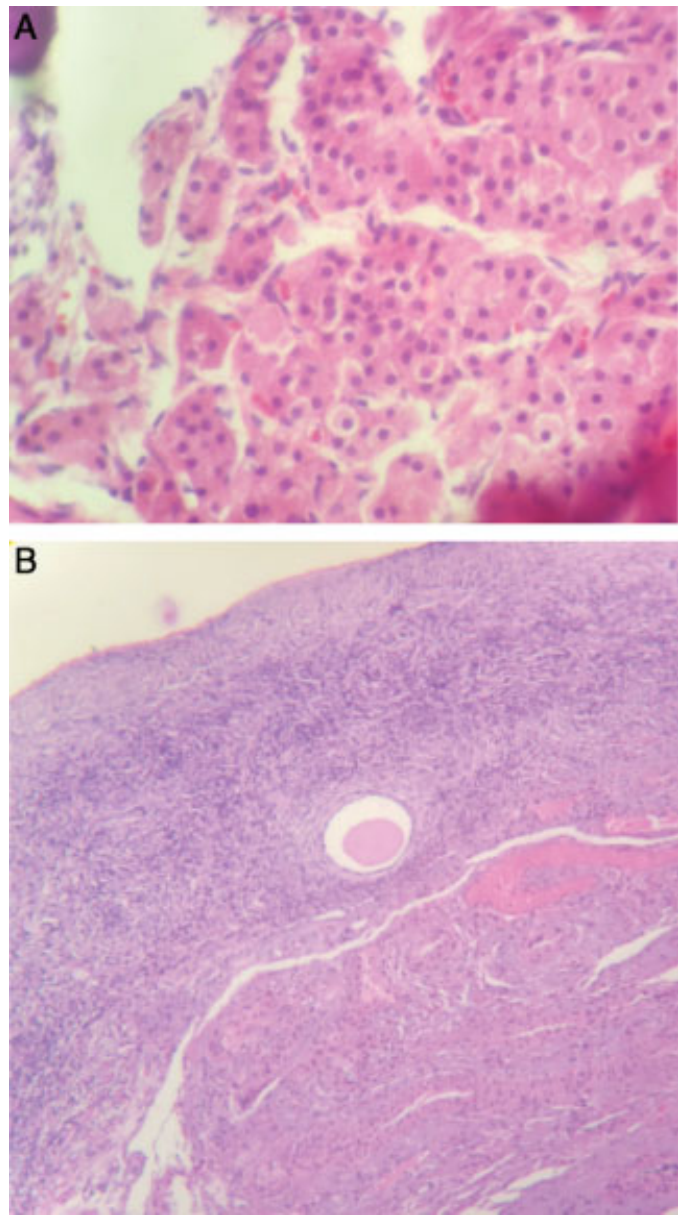

Fig. 4 Histologic sections. (A) Sertoli cell cumuli. (B) Ovarian follicle. 

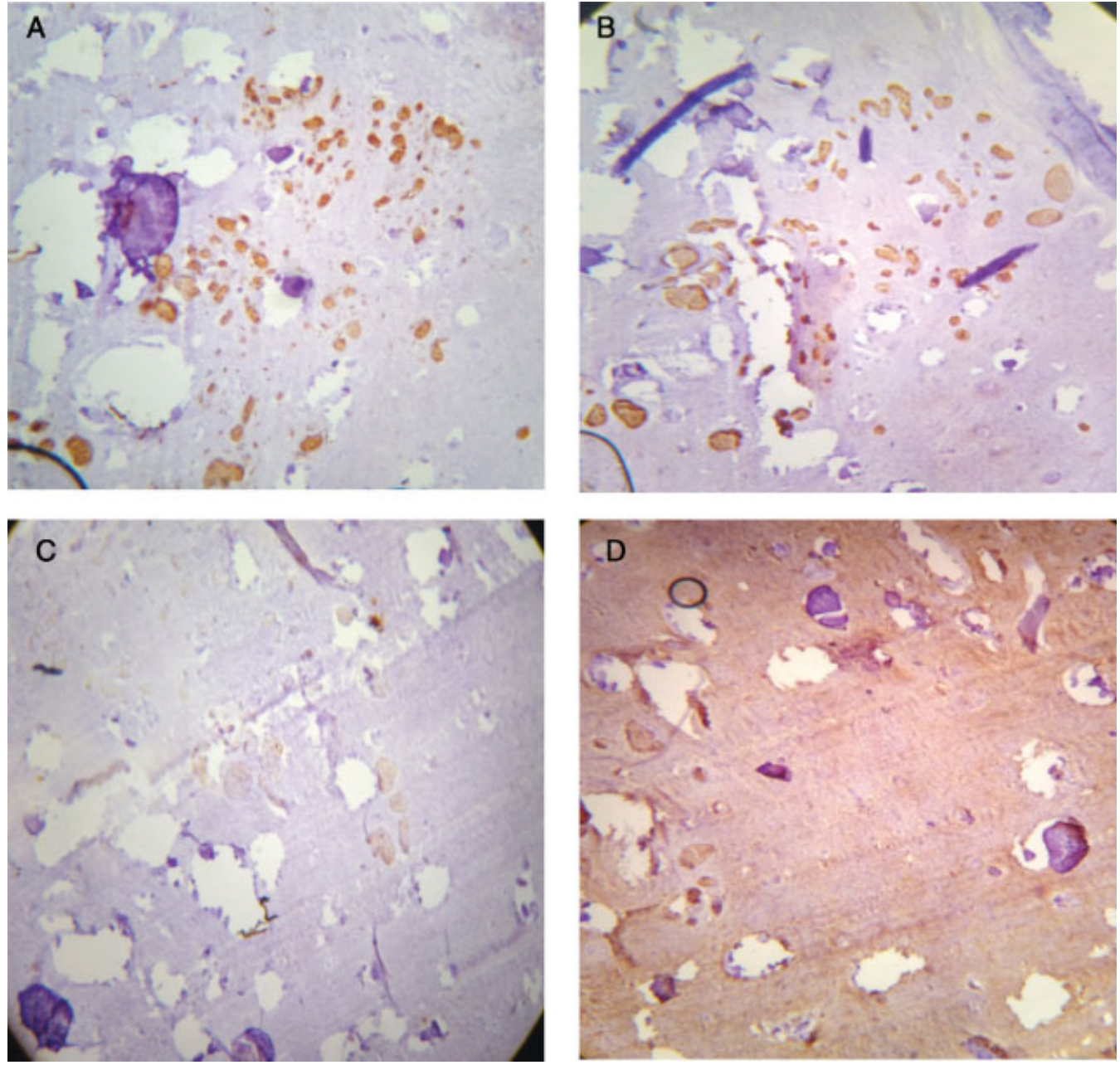

Fig. 6 Immunohistochemical markers. (A) Calretinin: positive. (B) Melan A: positive. (C) CK AE1/AE3: positive. (D) CD99: positive.

Conflict of interest

The authors declare that they have no conflicts of interest.

\section{References}

1 Pinsker J. Turner syndrome: updating the paradigm of clinical care. JClin Endocrinol Metab 97:2012 http://press.endocrine.org/ doi/full/10.1210/jc.2012-1245

2 Coley D, Kutasy B, Suyin K, Antao B. Gonadoblastoma in patients with 45,X/46,XY mosaicism: a 16-year experience. J Pediatric Urol D 2015 http://www.jpurol.com/article/S1477-5131(16)00062-0/fulltext

3 Oliveira R, Verreschi I, Lipay M, Eça L, Guedes A, Bianco B. Y chromosome in Turner syndrome: review of the literature. Sao Paulo Med J 127:2009 http://www.scielo.br/scielo.php?script=sci_arttext\&pid=S1516-31802009000600010

4 Højbjerg Gravholt C, Fedder J, Weis Naeraa R, Muller J. Occurrence of gonadoblastoma in females with Turner syndrome and Y chromosome material: a population study. JClin Endocrinol Metab 85:2011 http://press.endocrine.org/doi/10.1210/jcem.85.9.6800?url_ver= Z39.88-

5 Moon W, Geun Lee D. Ovarian sex cord tumor with annular tubules in a patient with Turner syndrome. J Korean Med Sci D 2009 (1998. 13.1.89) http://jkms.org/search.php?where=aview\&id=10.3346/jkms. 1998.13.1.89\& code=0063JKMS\&vmode=REF

6 Kurman RJ, Hedrick Ellenson L, Ronnett BM. Blausteins pathology of the female genital tract, 6th ed. New York: Springer; 2011

7 Yash C, Michael J, Andrew J. Role of the growth hormone IGF-1 axis in cancer. Expert Rev Endocrinol Metab 6;2011:71-84http:// www.tandfonline.com/loi/iere20\#.V1Xy1ZMeSko

\section{Further reading}

8 Dendrinos M, Smorgick N, Marsh C, Smith Y, Quint E. Ocurrence of gonadoblastoma in patients with 45,X/46,XY mosaicism. J Pediatr Adolesc Gynecol 28: 2015 http://www.jpagonline.org/article/ S1083-3188(14)00354-4/Abstract 